\title{
EMOTIONAL QUOTIENT AND THE SECOND YEAR STUDENTS' SPEAKING ABILITY OF ENGLISH EDUCATION DEPARTMENT
}

\author{
Muhammad Syahruddin Nawir \\ Universitas Islam Negeri Alauddin Makassar \\ muhammad.syahruddin.nawir@uin-alauddin.ac.id \\ Nur Aliyah Nur \\ Universitas Islam Negeri Alauddin Makassar \\ nuraliyahnur@uin-alauddin.ac.id \\ Muhammad Wiranto \\ Universitas Islam Negeri Alauddin Makassar \\ 20400117029@uin-alauddin.ac.id
}

\begin{abstract}
This study aims to find out the extent to which the significant correlation between emotional quotient and speaking ability on the second-year students in the major of English Education Department. This research used multi-stage cluster sampling to gather data on 30 students from the total population of 101 students. The researchers used quantitative approach with correlation research design to reach the research objective. There were two instruments distributed to students namely USMEQ-i questionnaire for measuring students' emotional quotient and Speaking Test for assessing students' speaking ability. The findings showed that the score of students' emotional quotient (2.85) was high emotional quotient by using USMEQ-i questionnaire and the score of students' speaking ability (70.83) was fairly good speaking by using Speaking Test. Furthermore, the coefficient correlation $\left(\mathrm{r}_{\mathrm{xy}}\right)$ was 0.886 . It indicated that the correlation was in high correlation. Based on the data above, the researchers conclude that the alternative hypothesis was accepted and null hypothesis was rejected. It means that there is a significant correlation between emotional quotient and speaking ability on second year students in the major of English Education Department. The researchers mention a suggestion to the teacher that emotional quotient should get serious attention to control, motivate, and regulate students' emotional quotient. If students are able to control their emotions, they will get good grade in speaking activity. In addition, for the next researchers, they have to collect many new sources for analyzing and evaluating this study.
\end{abstract}

Keywords: Emotional Quotient, Significant Correlation, Speaking Ability

\section{INTRODUCTION}

peaking is one of the important skills that we use to communicate and understand each other.

This skill is one of the productive skills. Speaking has big contribution to share and to get the information. Furthermore, speaking is the key to communicate as interactive process to develop meaning which involves production, reception, and process of information.

According to Nunan in Halima (2016), speaking is a productive skill which focuses on how learners use and communicate in the foreign language, but in fact, they speak in the classroom because speaking has much awareness of other communicative considerations such as making mistake in pronunciation, fluency, or grammatical structure. In addition, Rababa'h in Al-Hosni (2016) argued that 
there are many factors that cause difficulties in speaking English among EFL learners. In speaking ability, there are many difficulties which are found, because it is involved by many aspects like cognitive, psychological and psychomotor aspects.

Speaking ability is influenced by many components and related with the instruction of the holy Qur'an. Allah swt. said in the holy Qur'an surah An-Nisa : 63 (Al-Qur'an Al-Karim, 2010).

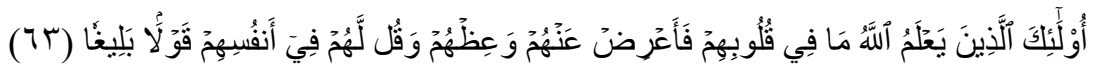

"They are people who (verily) Allah knows their hearts, Therefore, turn away from them, and give them advice, and say to them the words that imprint on their souls.” (Q.S. An-Nisa 4: 63)

From this verse, people who swear that they only want the kindness and guidance, Allah swt knew their hearts. Therefore, do not heed their words and lead them to the truth with good advice. Shihab (2002) mentioned that we have to tell those people the wisdom, until they take it into their hearts. It means that in speaking activity we need a major component namely wisdom. The wisdom describes the ability to control emotions. Furthermore, emotional controlling in speaking skill is involved by the emotional quotient.

The difficulties of speaking skill are not only about the low intelligence quotient (IQ). Marzuki, Mustaffa, \& Saad (2015) stated that emotional quotient was an important element to determine student's speaking skill and competencies in communication and information technology. Generally, the single entity intelligence quotient (IQ) was not guaranteed to be successful in life. It was said that individuals possess some abilities in using emotion in order to enhance thought effectively than others.

Emotional quotient concerns the process of one's appraisal of his own others' emotions, expressing feelings appropriately, processing emotional information and regulation of emotions to make the life better (Ghanadi \& Ketabi, 2014). Besides that, emotional quotient is not impacted by biological factors. So that everyone has the same chance to have emotional quotient.

The big problem of most people in learning English especially in speaking is their mindset that make them feel suppressed and burdened. The researchers think that it is the problem that teachers have to know and students must try to change their mindset because it extremely influences their speaking skill.

To change students' mindset, they must have emotional quotient. Emotional quotient is an important factor that should be possessed by the students who want to get high score in speaking class because emotional quotient is closely related to speaking ability. Aguilera (2012) stated that students need emotional quotient to use language and body language for keeping the listener in what they say and understand the meaning. If students have emotional quotient, they have the opportunity to achieve the speaking score, speak fluently, have good manner in speaking, and attract audiences. In the process of speaking activity, emotional quotient is really needed. Therefore, the researchers preferred to conduct a study on finding out the extent to which the significance correlation between emotional quotient and speaking ability. 
To make the research more specific, the researchers limited the discussion about speaking ability. The researchers used intensive speaking specifically read-aloud tasks. The scoring of read-aloud tasks is relatively easy because all of the test taker's oral production is controlled. Brown (2019) stated that the six components of speaking scoring are pronunciation, grammar, vocabulary, fluency, comprehension, and task. In this case, the researchers used two components of intensive speaking scoring that is pronunciation and fluency because Brown (2019) argued that for intensive speaking specifically read-aloud tasks, we assess with pronunciation and fluency. The researchers limited the discussion about emotional quotient. The researchers focused on seven aspects of emotional quotient based on Yusoff (2010) because they give big role to student's emotional quotient and have similarity with Indonesian culture. Those aspects are emotional control, emotional maturity, emotional conscientiousness, emotional awareness, emotional commitment, emotional fortitude, and emotional expression. The researchers concerned on second year students in major of English Education Department at Alauddin State Islamic University of Makassar because the second-year students learn about speaking and require the information about emotional quotient.

\section{REVIEW OF LITERATURE}

\section{Related Research Findings}

Firstly, Kurniasih (2018) stated that there is a positive correlation between emotional quotient, selfconfidence, and speaking ability on the eight-grade students of SMPN 2 Gambang Kromong Kebumen. A positive correlation means that the increase students' emotional quotient and self-confidence is followed by the increase in students speaking ability. Based on the research finding and conclusion, it was found that emotional quotient and self-confidence have a contribution in speaking ability. From the result of the study, the implication can be taken is the enhancing students' emotional quotient and selfconfidence have to enhance their speaking ability.

Secondly, Afshar \& Rahimi (2013) studied on the emotional intelligence and speaking skill. They investigated the relationship among critical thinking, emotional intelligence, and speaking abilities of Iranian EFL learners. The learners filled put the Bar-On emotional intelligence questionnaire, took the California Critical Thinking Skills Test (CCST) form B, and had an interview. The results of the study showed that emotional intelligence, followed by critical thinking, correlated with speaking abilities. All components of emotional intelligence correlated significantly with speaking ability and there was significant relationship between critical thinking and emotional intelligence.

Next, Marzuki et all., (2016) found the relationship between emotional intelligence with English speaking competence in terms of listening, speaking, reading, and writing. The correlation between emotional intelligence and speaking English competency showed there was significant relationship between emotional intelligence with frequency of speaking, reading, and writing; confidence in speaking and fluency in speaking; reading and writing; understand what is read and writing skills. These findings proved that the higher level of emotional intelligence, the higher frequency of speaking, 
reading, and writing; confidence and fluency in speaking; reading and writing; understand what is read and writing skills.

The last, Nwadinigwe \& Azuka Obieke (2012) studied the relation between emotional intelligence and student's academic achievement. According to their study, the emotional intelligence positively correlated with student's academic achievement. Students with high emotional intelligence have consciousness against the state of their emotions and the emotions of others and also able to control emotions that would help them to achieve the triumph of academic.

Furthermore, some findings above describe that there is a correlation between emotional quotient and speaking ability. In this research, the researchers focused on students' emotional quotient and students' speaking ability. As the conclusion, the researchers conducted the research with different subject, setting, and design with those previous findings. There are four findings about emotional quotient. The first finding was from Kurniasih (2018) that focused on emotional quotient and selfconfidence that have a contribution in speaking ability. The second finding was from Afshar \& Rahimi (2013) that focused on investigated the relationship among critical thinking, emotional intelligence, and speaking abilities of Iranian EFL learners. The third finding was from Najib Ahmad Marzuki (2016) that focused on relationship between emotional intelligence with English speaking competence in terms of listening, speaking, reading, and writing. The last finding was from Nwadinigwe \& Azuka Obieke (2012) that focused on the relation between emotional intelligence and student's academic achievement. In this research, the researchers focused on the correlation between emotional quotient and speaking ability. The researchers elaborated seven main aspects of emotional quotient specifically emotional control, emotional maturity, emotional conscientiousness, emotional awareness, emotional commitment, emotional fortitude, and emotional expression. The seven domains were correlated with the students' speaking ability. The researchers used intensive speaking namely read-aloud tasks. This research took a place on second year students in the Major of English Education Department.

\section{Definition of Speaking}

Brown (2019) pointed out that speaking is a productive skill that can be observed directly and empirically. Argawati (2014) stated that speaking covers many things in addition to the pronunciation of individual sounds. Thornbury (2005) said that speaking is interactive and requires the ability to cooperate in the management of speaking turns. It typically took place in real time with little time for detail the plan. Based on Solcova (2011), speaking as an interactive process in which individuals alternate in their roles as speaker and listeners and employ both verbal and non-verbal means to reach their communicative goals, speaking in a similar way saying that speaking is the process of building and sharing meaning through the use of verbal and non-verbal symbols, in a variety of contexts.

Based on those definitions of speaking, we can define that speaking ability is the students' capability of speech or increasing speaking or talking. The functions of speaking ability are to express an idea, feeling, thought, and needs orally. 


\section{The Elements of Speaking}

Brown (2019) stated that there are six components of speaking skill as in the following:

a. Pronunciation. Pronunciation cannot largely learn successfully by imitation and repetition. Therefore, teachers should have good standard of pronunciation in order that students can imitate their teacher in any teaching and learning process, but we cannot expect our students to sound exactly like American or Britain and the teachers should introduce the activities will be done in order to give the opportunities to make a lot of repetition.

b. Vocabulary. There are two types of vocabulary which are active and passive vocabulary. Active vocabulary is the words which the students will need to understand. Passive vocabulary is the words which we want the students to understand, but they will not use themselves.

c. Grammar. Grammar is word organization into various combinations that represents structures, such as phrase, sentences, and complete utterances. Grammar can be defined the way words to make a good sentence. The points of grammar are isolated and practice.

d. Fluency. Fluency does require a reasonable knowledge of vocabulary and grammar, the language produced does not need to be flawless as long as you are able to be clearly understood.

e. Comprehension. The strength of comprehension that is trained aims to improve or test a person understanding of spoken language. Comprehension can be defined as the ability to understand spoken English. Comprehension points out how well students understand spoken language.

f. Task. Task is speaking proficiency equivalent to that of an educated native speaker. Someone would rarely be taken for a native speaker but can respond appropriately even in unfamiliar situations and handle informal interpreting form and into language.

Brown (2019) mentioned that rating scales for intensive speaking specifically read-aloud tasks are pronunciation and fluency that incorporate read-aloud passage of about 120 to 130 words.

\section{Types of Speaking}

Brown (2019) said that there are some types of speaking as in the following taxonomy:

a. Imitative. Imitative speaking is an ability to simply imitate (follow) a word or phrase or possible sentences. While this purely phonetic level of oral production, a number of prosodic, lexical, and grammatical properties of language may be included in the criterion performance.

b. Intensive. The production of short stretches of oral language designed to demonstrate competence in a narrow band of grammatical, phrasal, lexical, or phonological relationships. Intensive speaking involves producing a limited amount of language in a high controlled context.

c. Responsive. Responsive include interaction and test comprehension but at the somewhat limited level of very short conversations, standard greeting and small greeting, simple requests, and comments. This is a kind of short replies to teacher or student-limited questions or comments, giving instruction, and directions. Those replies are usually sufficient and meaningful.

d. Interactive. The difference between interactive and responsive speaking is in the length and complexity of the interaction, which sometimes includes multiple exchanges or multiple 
participants. Interaction can take the two forms of transactional language, which has the purpose of exchanging specific information or interpersonal exchanges which have the purpose of maintaining social relationship.

e. Extensive (monologue). Extensive oral production tasks include speeches, oral representations, and storytelling, during which the opportunity for oral interaction from listener is either highly limited (perhaps to nonverbal responses) or ruled out together.

The speaking type in this research is intensive speaking as the designing assessment. There are several kinds of intensive speaking as the designing assessment, such as:

a. Directed response tasks. The test administrator elicits a particular grammatical form or a transformation of a sentence. Such task re clearly mechanical and not communicative, but they do require minimal processing of meaning in order to produce the correct grammatical output.

b. Read-aloud tasks. Intensive reading-aloud tasks include reading beyond the sentence level up to a paragraph or two. This technique is administrated by selecting a passage that incorporates test specs and by recording the test takers output. The scoring is relatively easy because all of the testtakers oral production is controlled.

c. Sentence/dialog completion tasks and oral questionnaires. Test takers are first given time to read through the dialogue to get its gist and to think about appropriate lines to fill in, then as the tape, teacher, or test administrator, produce one part orally, and test takers responds.

d. Picture-cued tasks. Picture cued stimulus requires a description from the test takers. Picture may be very simple, design to elicit a word or phrase, somewhat more elaborate or composed of a series that tells a story or incidents.

Therefore, the researchers used read-aloud tasks to assess intensive speaking. The procedure to assess intensive speaking using read-aloud task is the researchers selected a passage and gave it to the students. Then, the students record what they read. In addition, the researchers provided an assessment with students' recording.

\section{Concept of Emotional Quotient}

\section{Definition of Emotional Quotient}

Wechsler in Boehm (2011) defined that quotient as the aggregate or global capacity of the individual to act purposefully, to think rationally, and to deal effectively with his (or her) environment. While Gottfredson (2002) stated that intelligence (quotient) is a very general mental capability that among other things, involves the ability to reason, plan, solve problems, think abstractly, understand complex ideas, learn immediately and learn from the experience.

According to Barrett (2006), emotions are the level of perception and apparently have no place for the idea of interactions among distinct features of emotion and cognition. Emotion is one particular typical mind and feeling, and situation biologist and psychological and refers to the intelligence to act (Goleman, 2002).

Goleman (2002) defined that emotional quotient as understanding one's own feelings, empathy for 
the feelings of others and the regulation of emotion in a way that enhances living. According to Bar-On (2006) emotional quotient is a set of abilities, competencies, and skill that influence one's ability to be success in overcoming environmental demands and pressures. Emotional quotient addresses the emotional, personal, social, survival dimension of intelligence.

Grant \& Kinman (2013) argued that emotional quotient is the ability to motivate oneself and persist in the face of frustrations, to control impulse and delay gratification, to regulate one's moods and keep distress from swamping the ability to think, to empathize and to hope. Emotional quotient is the ability to identify, understand, and manage moods and feelings, in bot ourselves and other people. Emotional quotient refers to the competence to identify and express emotions, understand emotions, assimilate emotions in thought, and regulate both positive and negative emotions in the self and in others (Ahmadi, 2014).

The researchers conclude that quotient is an ability which affects performance to solve problem, to create product, to think abstractly and to achieve goals, and emotion is the energy that leads one's condition to give to the way of the body reacts to certain situation. Therefore, emotional quotient is ability to sense understand, express, and regulate emotion in a way that enhance living.

\section{Characteristics of Emotional Quotient}

Based on Goleman (2002), the characteristics of emotional quotient (EQ) are abilities such as being able to motivate one and persist in the face of frustrations, to control impulse and to put off gratification, to organize one's mood and maintain the distress from swamping the ability for thinking, empathizing and hoping. Emotional quotient is very important for students to learn and improve even though it is stated that IQ cannot be changed significantly by experience or education.

\section{Aspects of Emotional Quotient}

Goleman (2002) adapted the emotional quotient into five aspects of capabilities consisting of:

a. Self-awareness: namely the ability of a person to know what he felt at a time, and use it to guide decisions for themselves. Having a realistic benchmark for the ability of self and the confidence is strong. Goleman (2002) added that self-awareness enables rational thought to provide important information to get rid of an unpleasant mood. At the same time, self-awareness can help to manage yourself and inter-personal relationship and realize their emotions and thoughts.

b. Self-regulation: the ability to recognize one's own emotions that have a positive impact on the execution of tasks, sensitive to the conscience, could delay the enjoyment before the achievement of a goal and were able to recover from the emotional stress.

c. Self-motivation: the ability to use the deepest desire to move and lead toward a goal, able to take initiative and act effectively, and able to withstand failure and frustration.

d. Empathy: the ability to sense what is perceived by others, cultivate a relationship of trust, and there are able to align themselves with various type of people.

e. Social skill: the ability to positive control emotions when dealing with social care, can interact smoothly, using these skills to influence, lead, deliberation, solve problems, and cooperation in 
teams.

Shapiro (2003) organized aspect of emotional quotient into six areas, among others: the ability associated with moral behavior, ways of thinking, problem solving, social interaction, academic success and employment as well as emotions.

Yusoff (2010) proposed the different aspects of emotional quotient which is divided into seven domains, as follows:

a. Emotional control: the ability of self-control from disruptive emotions and impulsive feelings.

b. Emotional maturity: the ability to facilitate and guide emotional tendencies to achieve and reach intended goals.

c. Emotional conscientiousness: the ability of taking responsibility and maintaining integrity for personal performance.

d. Emotional awareness: the ability of knowing and understanding one's own and other person's internal states, preferences, resources, and intuitions as well as their effects.

e. Emotional commitment: the ability of aligning and working with others in a group or organization towards common goals.

f. Emotional fortitude: the ability of negotiating and resolving disagreements as well as sending convincing messages.

g. Emotional expression: the ability of conveying and adjusting one's emotions, thoughts and behaviors to change condition and situations.

There are several components of emotional quotient based on Goleman (2002), Shapiro (2004), and Yusoff (2010). From the theories, the basis for this research is from Yusoff (2010) that classified emotional quotient into seven domains specifically emotional control, emotional maturity, emotional conscientiousness, emotional awareness, emotional commitment, emotional fortitude, and emotional expression.

\section{METHOD}

\section{Research Method}

This research used quantitative approach with correlation research design to gather data about students' emotional quotient and students' speaking ability, and rely on the use of correlational analysis to determine if there is a significant correlation between emotional quotient and speaking ability. In this research, the researchers employed the quantitative research and its approach was correlation research design. Williams (2011) stated that quantitative approach is to give response to the research questions in requiring numerical data. It means that quantitative approach requires numerical data, numbers, and statistic.

\section{Population and Sample}

According to Creswell (2012), population is the group of individuals that has the same characteristics. Based on the statement, we can conclude that population is the subjects or individuals that have the same characteristics in research. The population of this research is second year students 
in the major of English Education Department which consists of 3 classes: PBI A 35 students, PBI B 34 students, and PBI C 32 students, so the total number of the population is 101 students.

Furthermore, the researchers used multi-stage cluster sampling to determine the sample. Creswell (2012) defined that multi-stage cluster sampling is the technique that the researcher is able to use to make the identification study easily if the population is very large. In this technique, the researchers selected the sample of 15 students from PBI A and 15 students from PBI B.

\section{Research Instrument}

The researchers used two kinds of instruments, namely: test and questionnaire as the instruments of this research. The speaking test was systematically done by guidance rubric of speaking according to Heaton as cited in Rusdi (2015). The test that was given by the researchers was read-aloud tasks with the text from Longman TOEFL Test in reading section about Carbon Tetrachloride. According to Brown (2004), two main aspects in read-aloud tasks are pronunciation and fluency. He added that readaloud passage consists of 120 to 130 words. The researchers used the test to collect data about students' speaking ability.

Furthermore, the researchers used the close questionnaire to know the students' emotional quotient. The researchers used Universiti Sains Malaysia Emotional Quotient Inventory (USMEQ-i) by Yusoff (2010). It was developed to assess the emotional quotient because the similarity of Indonesian and Malaysian culture. In addition, the researchers used Indonesian version of USMEQ-I to avoid misunderstanding.

USMEQ-i consists of 46 items, based on seven domains of emotional quotient and faking index. Faking index measures the tendency of respondents to overrate themselves. Faking index is grouped into 3 groups: low $=0.00$; average $=2.01-2.99$; high $=3.00-4.00$. If the score of faking index is high, it means that the result of the respondents is not reliable. It may not show the true colors of the respondent's emotional quotient. It is supposed to the further analysis such as counter check with friends' or lectures' opinion regarding the results and the respondent's characteristics.

\section{Data Analysis Technique}

In this research, the researchers analyzed students' speaking ability by using scoring rubric by Heaton in Rusdi (2015). The speaking criteria assessed in this research were pronunciation and fluency as the speaking task only required to asses those two aspects. The next analysis techniques was scoring the students' speaking ability, classifying the scores, calculating the mean score, then further comparing the mean scores with the score of UMSEQ-I (Yusoff, 2010) using SPSS application in order to examine the correlation between students' speaking ability and the emotional quotient. To interpret the correlation value or level, the researchers used the following rubric (Hadi in Arikunto, 2013):

Table 1. Classification of Correlation Level

\begin{tabular}{cc}
\hline r Values & Interpretation \\
\hline $\mathbf{0 . 8 0 0}-\mathbf{1 . 0 0}$ & High correlation \\
\hline $\mathbf{0 . 6 0 0}-\mathbf{0 . 8 0 0}$ & Quite high correlation \\
\hline $\mathbf{0 . 4 0 0}-\mathbf{0 . 6 0 0}$ & Fairly low correlation \\
\hline
\end{tabular}




\begin{tabular}{cc}
\hline $\mathbf{0 . 2 0 0}-\mathbf{0 . 4 0 0}$ & Low correlation \\
\hline $\mathbf{0 . 0 0 0}-\mathbf{0 . 2 0 0}$ & Very low (there is no correlation) \\
\hline
\end{tabular}

\section{FINDINGS AND DISCUSSION}

\section{Findings}

The findings of this research identify students' emotional quotient score with the questionnaire, students' speaking score with the text and analyze the correlation below:

Classification of students' speaking score

Table 2. Distribution of Students' Speaking Frequencies and Percentage

\begin{tabular}{cccc}
\hline Score & Criteria & Frequencies & Percentage \\
\hline $\mathbf{9 0 - 1 0 0}$ & Very good & 6 & $20 \%$ \\
\hline $\mathbf{8 0 - 8 9}$ & Good & 5 & $17 \%$ \\
\hline $\mathbf{7 0 - 7 9}$ & Fairly good & 7 & $23 \%$ \\
\hline $\mathbf{6 0 - 6 9}$ & Poor & 7 & $23 \%$ \\
\hline$\leq \mathbf{5 9}$ & Very Poor & 5 & $17 \%$ \\
\hline \multicolumn{2}{c}{ Total } & 30 & $100 \%$ \\
\hline
\end{tabular}

Table 1.4 showed that $6(20 \%)$ students were very good speaking, 5 (17\%) students were good speaking, 7 (23\%) students were fairly good speaking, 7 (23\%) students were poor speaking, and 5 $(17 \%)$ students were very poor speaking. It meant that the highest percentage of students' speaking score were fairly good and poor. Both of the items were $23 \%$.

The mean score of students' speaking ability

Table 3. The Mean Score of Students' Speaking Score

Mean Score $\quad \mathbf{7 0 . 8 3}$

The mean score (70.83) indicated that the students' speaking ability on second year students in the major of English Education Department was fairly good.

\section{Result and classification of students' emotional quotient score}

Table 4. The Descriptive Statistics of Emotional Quotient

\begin{tabular}{ccccccc}
\hline & N & Range & Minimum & Maximum & Sum & Mean \\
\hline $\begin{array}{c}\text { USMEQ-i } \\
\text { Valid N } \\
\text { (Listwise) }\end{array}$ & 30 & 2.02 & 1.89 & 3.91 & 85.83 & 2.85 \\
\hline
\end{tabular}

Based on the descriptive statistics above, the range score of USMEQ-i was 2.02, the minimum score was 1.89, and the maximum score was 3.91. Besides that, the sum score was 85.83 and the mean was 2.85. The mean score (2.85) was indicated that the level of emotional quotient on second year students in the major of English Education Department was high. The distribution of students' emotional quotient was in the table below:

Table 5. The Distribution of Emotional Quotient

\begin{tabular}{cccc}
\hline Score Interval & Criteria & Frequency & Percentage \\
\hline $\mathbf{2 . 8 1 - 4 . 0 0}$ & High & 10 & $33 \%$ \\
\hline $\mathbf{1 . 2 1 - 2 . 8 0}$ & Average & 20 & $67 \%$ \\
\hline
\end{tabular}




\begin{tabular}{ccccc}
\hline $\mathbf{0 - 1 . 2 0}$ & & Low & - & - \\
\hline & Total & & 30 & $100 \%$ \\
\hline
\end{tabular}

From the table distribution of USMEQ-i above, the result pointed out that 10 students were in the high emotional quotient (2.81-4.00), 20 students were in average (1.21-2.80), 0 student was in the low emotional quotient.

\section{Classifying the correlation by using Pearson Product Moment}

The calculation showed that the coefficient correlation between emotional quotient and speaking ability was 0.886 . It means that the alternative hypothesis was accepted and the null hypothesis was rejected. There was a significant correlation between emotional quotient and speaking ability on second year students in the major of English Education Department.

Table 6. The Classification of Coefficient Correlation Level

\begin{tabular}{cc}
\hline r values & Interpretation \\
\hline $\mathbf{0 . 8 0 0 - 1 . 0 0}$ & High correlation \\
\hline $\mathbf{0 . 6 0 0 - 0 . 8 0 0}$ & Quite High correlation \\
\hline $\mathbf{0 . 4 0 0 - 0 . 6 0 0}$ & Fairly Low correlation \\
\hline $\mathbf{0 . 2 0 0 - 0 . 4 0 0}$ & Low correlation \\
\hline $\mathbf{0 . 0 0 0 - 0 . 2 0 0}$ & Very low (there is no correlation \\
\hline
\end{tabular}

Based on the data above, it showed that the coefficient correlation between emotional quotient and speaking ability (0.886) was high correlation. It means that the null hypothesis was rejected and the alternative hypothesis was accepted. There was a significant correlation between emotional quotient and speaking ability on second year students in the major of English Education Department.

\section{Discussion}

Based on the result of USMEQ-i, it showed that emotional quotient of second year students in the major of English Education Department was high. High level proposed that second year students in the major of English Education Department can manage their emotion and direct to useful activity. Yusoff (2010) stated that high score of USMEQ-i indicates that students can perceive, understand, express, control, motivate, and regulate their emotional quotient.

Based on the result of speaking test, it pointed out that second year students in the major of English Education Department was fairly good in speaking. According to Brown (2019), fairly good means that students was influenced by mother tongue with a few errors, and dominated by several grammatical and lexical errors. Besides, students have to clarify some information such as sentence and phrase.

On the other hand, the result of coefficient correlation showed that alternative hypothesis was accepted. The score of coefficient correlation (0.886) was high correlation. It indicated that there is significant correlation between emotional quotient and speaking ability on second year students in the major of English Education Department.

This research needed some related findings to strengthen the result. The result was there is significant correlation between emotional quotient and speaking ability on second year students in the 
major of English Education Department. It meant that if students had good emotional quotient, they would achieve good speaking ability.

The first finding was Farooq (2017) stated that there is a positive relationship between emotional quotient and academic success of students. Students in high emotional quotient was in high level of academic success. In this findings, male students have higher statistics than female students but it is not statistically significant.

The second finding was from Gench, Kullusakli, Aydin (2016) that focused on the relationship between emotional intelligence and productive language skills. The study examined language speaking skills and writing with 150 students from different disciplines of the university and studying English as foreign language in Turkey. The result of this study showed that positive correlation between emotional intelligence and productive skills.

The third finding was from Yunita (2016) showed that there was positive correlation between emotional intelligence and their speaking achievement. The research was investigated by the Indonesian University student to get her second bachelor degree with the object of fourth semester students. The researcher used quantitative research method. For the EI test, students answered 60-item questionnaire based on Goleman's theory. For the oral test, the researcher applied interview, reading aloud, description tasks, and role plays. The result also showed that the self-control was the best predictor to predict students in English speaking ability.

The fourth finding was from Rafleyan, Nejad, and Damavand (2014) who investigated the relationship between emotional intelligence and pragmatic awareness. The participants were 120 Iranian senior undergraduates of English as foreign language in university in Iran. The result showed positive correlation between emotional intelligence and pragmatic awareness.

The fifth finding was from Asadollahfam (2012) who investigated the relationship between emotional intelligence and language learners' vocabulary knowledge. The participants were 50 learners of English as a foreign language at a university in Iran. The data were collected by Nation's Word Level Test (2001) to assess language learners' vocabulary size and Bar-On's Emotional Intelligence Questionnaire (1997) to assess their emotional intelligence score. The result showed that language learners with high levels of emotional intelligence posed a high levels of vocabulary knowledge.

Based on those findings, it is indicated that emotional quotient has a significant correlation with speaking ability. It is in line with the results of this research that there is a significant correlation between emotional quotient and speaking ability on second year students in the major of English Education Department with a high correlation level (0.886). Therefore, students who can speak fluently and accurately are certainly able to control, manage, and motivate their emotions. If the students have strong emotional quotient, their speaking skill can get better. 


\section{CONCLUSION}

Based on the result of the data, the researchers found that the emotional quotient on second year students in the major of English Education Department was high emotional quotient with the mean score 2.85 and the speaking ability on second year students in the major of English Education Department was fairly good speaking ability with the mean score 70.83. Moreover, the coefficient correlation 0.886 was high correlation (there was a significant correlation). It showed that alternative hypothesis was accepted and null hypothesis was rejected. The conclusion is it can be categorized as the significant correlation between emotional quotient and speaking ability on second year students in the major of English Education Department.

\section{REFERENCES}

Afshar, H.S. and Rahimi M. (2013). The Relationship among Critical Thinking, Emotional Intelligence, and Speaking Abilities of Iranian EFL Learners. Procedia Social and Behavioral Sciences. Vol.2. 45-66.

Aguilera. (2012). Productive Language Skills Learning and Teaching: Speaking and Writing. Licenciada En Filologia.

Al-Hosni, Samira. (2021, 18 March). Speaking Difficulties Encountered by Young EFL Learners. International Journal on Studies in English Language and Literature (IJSELL). Vol.1. 21-42.

Argawati, N. O. (2014). Improving Students' Speaking Skill Using Group Discussion. ELTIN Journal. Vol.2. 74-81.

Arifin, W. N., Yusoff, M. S. B., \& Naing, N. N. (2012). Confirmatory Factor Analysis (CFA) of USM Emotional Quotient Inventory (USMEQ-i) among Medical Degree Program Applicants in Universiti Sains Malaysia (USM). Education in Medical Journal. Vol. 4(2). 26-44.

Arikunto, S. (2013). Prosedur Penelitian: Suatu Pendekatan Praktik. Jakarta: Rineka Cipta.

Asadollahfam, H., Salimi, A., \& Pashazadeh, F. M. (2012). Emotional intelligence, Gender and Vocabulary. Social and Behavioral Science. 46. 833-837.

Bar-On, R. (2006). The Bar-On Model of Emotional-Social Intelligence (ESI). Psichotema. 18. 13-25.

Barrett LF, Niedenthal PM, Winkielman P. (2005). Emotion and Consciousness. New York: Guilford.

Brown, H. Douglas. (2019). Language Assessment: Principle and Classroom Practices. New York: Addison Wesley Longman Inc.

Creswell, John W. (2012). Educational Research: Planning, Conducting, and Evaluating Quantitativ and Qualitative Research. $4^{\text {th }}$ ed. Boston: Person.

Departemen Agama RI. (2010). Al-Qur'an Al-Karim. Semarang: CV. Toha Putra.

Farooq, M. U., Riaz, K., \& Javid, C. Z. (2017). Impact of Emotional Intelligence on Academic Achievement of English Language Learners. Journal of Social Sciences and Humanities. Vol. 25. No. 2.

Gay. L. R. et al. (2016). Educational Research Competences for Analysis and Application. $8^{\text {th }}$ Ed. Colombus: Pearson Merrill Prentice Hall. 
Ghanadi, Z., \& Ketabi, S. (2014). The Relationship between Emotional Intelligence and Learners' Beliefs about Language Learning: Iranian Advanced EFL Learners in Focus. Theory and Practice in Language Studies. Vol. 4(3). 518-523.

Goleman, D. (2002). Emotional Intelligence: Kecerdasan Emosional, Mengapa EL Lebih Penting Dari Pada IQ. Jakarta: Gramedia.

Gottfredson, Linda S. (2002). The General Intelligence Factor. Copyright American Scientific. 24-30. USA: University of Delaware.

Grant \& Kinman. (2013). The Importance of Emotional Resilience for Staff and Students in the 'Helping' Professions: Developing an Emotional Curriculum. England: University of Bedfordshire.

Grench, G., Kulusakli, E., \& Aydin, S. (2016). The Relationship between Emotional Intelligence and Productive Language. An International Online Journal. Vol. 16(1). 91-105.

Kurniasih, Nuniek. (2018). The Correlation between Emotional Quotient, Self Confidence, and Speaking Ability in The Eighth Grade Students of SMP N 2 Gombong Kebumen in The Academic Year of 2017/2018. Thesis. IAIN Suarakarta.

Marzuki, Mustaffa \& Saad. (2015). Emotional Intelligence: Its Relationship with Communication and Information Technology Skills. Published by Canadian Center of Science and Education. Asian Social Science. Vol. 11(15). 266-274.

Nwadinigwe, I.P and Azuka-Obieke, U. (2012). The Impact of Emotional Intelligence on Academic Achievement of Senior Secondary School Students in Lagos, Nigeria. Journal of Emerging Trends in Educational Research and Policy Studies (JETERAPS). Vol. 3(4). 395-401.

Rafieyan, V., Nejad, M. S., Davamand, A., Eng, L. S., \& Mohamed, A. R. (2014). Relationship between Emotional Intelligence and Pragmatic Awareness. Australian International Academic Centre. 3(4). 143-149.

Rusdi, Sity Yudiarti Fajriah. (2015). Improving the Student's Speaking Ability by Using Thematic Materials A Class Action Research to the First Year Students of Mtsn. Model Makassar. Thesis. UIN Alauddin Makassar.

Shapiro, Lawrence E. (2003). Mengajarkan Emotional Intelligence pada Anak (Terjemahan Alex Tri Kantjono). Jakarta: Gramedia Pustaka Utama.

Shihab, M. Quraish. (2002). Tafsir Al-Misbah. Jakarta: Lentera Hati.

Thornbury, Scott. (2005). How to Teach Speaking. England: Longman.

Williams, C. (2011). Research Methods. Journal of Business \& Economics Research (JBER). 5(3).

Yunita.E.E. (2016). An Investigation into the Relationship between Emotional Intelligence and Students' English Speaking Ability. Bandung Education University.

Yusoff, M. S. B. (2012). Stability of USMEQ-i in Measuring Emotional Intelligence in Medical Students. ASEAN Journal of Psychiatry. Vol. 13(1). 1-6. 